\title{
Control of peptides regulating mitosis of granulosa cells in immature rat ovary by oestrogen and gonadotrophin
}

\author{
A. Chakravorty*, V. B. Mahesh and T. M. Mills \\ Department of Physiology and Endocrinology, Medical College of Georgia, Augusta, GA 30912, \\ USA
}

Previous studies in this laboratory have demonstrated the presence of a peptide that inhibits granulosa cell proliferation in medium sized follicles. This peptide was produced after 72-96 h of exposure to diethylstilboestrol (DES). This study analyses oestrogen and gonadotrophin modulation of this and another stimulatory peptide found in large follicles. Intact, immature, female rats were assigned to the following study groups: (i) one to four injections of DES ( $2 \mathrm{mg}$ per rat) given at intervals of $24 \mathrm{~h}$, animals killed $24 \mathrm{~h}$ after the last injection; (ii) DES at 0 and $24 \mathrm{~h}$, animals killed 24 or $48 \mathrm{~h}$ after the last injection; and (iii) DES plus pentobarbital ( $37 \mathrm{mg} \mathrm{kg}^{-1}$ body weight) at $30 \mathrm{~h}$, animals killed $48 \mathrm{~h}$ after the last injection. Small, medium and large follicles (diameters of $<200,200-400$ and $>400 \mu \mathrm{m}$, respectively) were isolated from ovaries, granulosa cells were harvested and follicular fluid supernatant (FFS) was collected. FFS proteins were tested for their effects on incorporation of $\left[^{3} \mathrm{H}\right]$ thymidine into granulosa cell DNA. Results showed that unfractionated FFS protein $(150 \mu \mathrm{g})$ from medium follicles in groups (i) (three and four injections only), (ii) and (iii) inhibited [ $\left.{ }^{3} \mathrm{H}\right]$ thymidine incorporation. Pentobarbital blockage of gonadotrophin secretion had no effect on the inhibitory peptide activity and two injections of diethylstilboestrol were enough to stimulate synthesis of the inhibitory peptide, provided sufficient time was allowed; FFS protein $(150 \mu \mathrm{g})$ from large follicles was stimulatory, but only when it was collected $24 \mathrm{~h}$ after the second injection, and the effect was abolished with pentobarbital treatment. Fractionation of pooled FFS into proteins with three molecular mass ranges $(<10 \mathrm{kDa}, 10$ $30 \mathrm{kDa}$ and $>30 \mathrm{kDa}$ ) showed that the inhibitory activity was in the $<10 \mathrm{kDa}$ fraction while the $>30 \mathrm{kDa}$ fraction stimulated thymidine incorporation. The number of medium and large follicles increased $24 \mathrm{~h}$ after the second DES injection, but the number of granulosa cells in the large follicles was significantly reduced after pentobarbital blockage of gonadotrophins. Taken together, these findings show that (i) the inhibitory peptide is induced in effective amounts in the medium follicles $48 \mathrm{~h}$ after the second DES injection and induction is not modulated by gonadotrophins; and (ii) stimulatory activity seen in the large follicles is transient and under gonadotrophic control, since blockage of follicle-stimulating hormone ( $\mathrm{FSH}$ ) secretion led to loss of stimulatory activity and a resulting reduction in number of granulosa cells in large follicles. We, therefore, propose that, besides recruiting small follicles, FSH boosts large follicle growth in the penultimate stages of follicle development via the synthesis of a stimulatory peptide of molecular mass $>30 \mathrm{kDa}$. Medium follicle growth, however, is regulated more by the oestrogen-induced inhibitory peptide.

\section{Introduction}

Ovarian folliculogenesis is characterized by rapid growth of small primary follicles, with few granulosa cells, to mature preovulatory follicles with several layers of cells. Thus, granulosa cell proliferation is an important feature in this developmental process. The well-known mitotic regulators are follicle stimulating hormone (FSH), oestradiol and possibly luteinizing hormone ( $\mathrm{LH}$; Richards, 1980; Bogovich et al., 1981). The nature of the proliferative response to these hormones depends on the *Present address: The Women's Research Institute, University of Kansas School of Medicine, Wichita, KS 67214-4716, USA.

Received 7 January 1992 specific stage of development, and hence the size of the follicles. Whereas Hirshfield (1985) has shown that, in rats, FSH stimulates only certain classes of follicle to grow more rapidly, studies from our laboratory have shown that oestrogens stimulate small follicles and inhibit medium follicle growth (Chakravorty et al., 1991b). This suggests that the rate of granulosa cell proliferation is controlled at each stage by separate hormonal cues.

The exact mechanism by which gonadotrophins and oestradiol control granulosa cell mitosis is not completely understood. Both FSH and oestrogens are known to be mitogenic in vivo, but neither hormone exhibits a marked effect in vitro, suggesting that these hormones might act indirectly by stimulating 
mitogenic factors. There is substantial evidence that several peptide growth factors are involved (Gospodarowicz and Bialecki, 1979). Some of these factors are present in the ovary and are produced locally (Adashi et al., 1985; Dorrington et al., 1988; Lobb et al., 1988), regulating granulosa cell proliferation in an autocrine or paracrine manner. Some of these factors may also be present in follicular fluid. The present study analyses the growth inhibitory and stimulatory properties of factors present in follicular fluid from small, medium and large follicles on $\left[{ }^{3} \mathrm{H}\right]$ thymidine incorporation in response to diethylstilboestrol (DES) and pituitary gonadotrophins. Previous studies in our laboratory have shown that there is a gonadotrophin surge at $36 \mathrm{~h}$ when DES was given to intact, immature rats at 0 and $24 \mathrm{~h}$ (Chakravorty et al., 1991a) and that growth of medium and large follicles is stimulated $12 \mathrm{~h}$ after this surge. In contrast, 72-96 h of DES treatment caused an inhibition of growth, specifically of medium follicles. We have shown that the inhibition is due to the synthesis of a peptide factor, which we call 'granulosa cell mitostatic peptide' (GCMP) since it inhibits granulosa cell mitosis. The objective of the present study was to characterize GCMP and detect a stimulatory peptide found in follicular fluid. The studies were designed to investigate gonadotrophic modulation of the activity of these peptides by blocking the endogenous gonadotrophin surges by treatment with pentobarbital and testing for activity of the peptides in follicular fluid supernatant on $\left[{ }^{3} \mathrm{H}\right]$ thymidine incorporation into granulosa cell DNA.

\section{Materials and Methods}

\section{Animals}

Intact, immature female Sprague-Dawley rats were obtained from Holtzman Laboratories (Madison, WI). The animals were housed in temperature-controlled $\left(22^{\circ} \mathrm{C}\right)$ quarters with $14 \mathrm{~h}$ light and $10 \mathrm{~h}$ darkness and provided with commercial rat chow and water ad libitum.

\section{Experimental protocol}

Four sets of studies were done with animals assigned to different groups for different regimens of treatment either with $2 \mathrm{mg}$ of diethylstilboestrol (Steraloids Inc., Wilton, NH) per rat subcutaneously in $0.2 \mathrm{ml}$ of propylene glycol or with pregnant mares' serum gonadotrophin (PMSG).

Experiment 1. Animals were assigned to four treatment groups according to the number of DES injections given: one, two, three or four injections at intervals of $24 \mathrm{~h}$. All animals were killed by decapitation at 28 days of age and $24 \mathrm{~h}$ after the last injection. The treatment groups were designated by the number of DES injections given at times before killing (indicated in parentheses): one $(24 \mathrm{~h})$, two $(48 \mathrm{~h})$, three $(72 \mathrm{~h})$ and four ( $96 \mathrm{~h})$.

Experiment 2. Two injections of DES at 0 and $24 \mathrm{~h}$ were given and animals were killed at 48 or $72 \mathrm{~h}$, i.e. 24 or $48 \mathrm{~h}$ after the second injection.
Experiment 3. Two injections of DES at 0 and $24 \mathrm{~h}$ were given, with or without treatment with pentobarbital $(37 \mathrm{mg}$ $\mathrm{kg}^{-1}$ body weight) given intraperitoneally $6 \mathrm{~h}$ after the second injection (at $30 \mathrm{~h}$ ). The animals were killed at $72 \mathrm{~h}$ ( $48 \mathrm{~h}$ after the second injection of DES).

Experiment 4. A single injection of PMSG, 8 iu per rat in $0.2 \mathrm{ml}$ of $0.9 \%(\mathrm{w} / \mathrm{v})$ saline, was given at $0 \mathrm{~h}$ to two groups of animals 26 days old. One group was killed at $24 \mathrm{~h}$ and the other group was killed at $48 \mathrm{~h}$ after PMSG administration. Follicular fluid supernatant (FFS) was collected and tested for effects on $\left[{ }^{3} \mathrm{H}\right]$ thymidine incorporation into granulosa cell DNA.

All animals were kept on a lighting schedule of $14 \mathrm{~h}$ light and 10 h darkness, lights being on between 05:00 and 19:00 h Eastern Standard Time (USA). All injections at $0 \mathrm{~h}$ were given at 06:00 h.

\section{Follicle isolation, granulosa cell extraction and collection of follicular supernatant fluid}

The ovaries were removed and cleaned of fat; follicles were isolated and separated by size; and granulosa cells were then harvested from follicles of three sizes as described previously (Chakravorty et al., 1991a). Rates of $\left[{ }^{3} \mathrm{H}\right]$ thymidine incorporation in these cells were measured as described previously (Chakravorty et al., 1991a). Follicular fluid supernatant was collected (Chakravorty et al., 1991a,b) after rupturing the follicles in a measured amount of buffer and separating the granulosa cells by centrifugation $(50 \mathrm{~g}$ for $5 \mathrm{~min})$. Protein content of FFS samples was measured (Lowry et al., 1951).

\section{Cell culture for effects of follicular fluid proteins}

The granulosa cell culture system used for testing the effects of FFS on $\left[{ }^{3} \mathrm{H}\right]$ thymidine has been described (Chakravorty et al., 1991a). Briefly, $1.25 \times 10^{5}$ viable granulosa cells from mediumsized follicles, collected after two injections of DES, were plated in $22.6 \mathrm{~mm}$ wells containing McCoy's $5 \mathrm{~A}$ buffer with Hepes and L-glutamine and $1 \%$ fetal calf serum (Gibco, treated with charcoal to remove steroids). These cells, chosen for high mitotic activity, were incubated without (control) or with FFS protein in duplicate, or with $150 \mu \mathrm{g}$ of bovine serum albumin (to eliminate non-specific protein effects). Two doses (150 and $300 \mu \mathrm{g}$ ) of unfractionated FFS protein from small, medium and large follicles, collected after the different treatment regimens, were added to the cell culture. The cells were incubated for $36 \mathrm{~h}$, then $0.5 \mu \mathrm{Ci}$ [methyl ${ }^{3} \mathrm{H}$ ] thymidine (ICN Radiochemicals, Irvine, $C A$; specific activity $=37 \mathrm{Ci} \mathrm{mmol}^{-1}$ ) was added to each well and the culture continued for an additional $12 \mathrm{~h}$. The cells were then washed three times with ice-cold buffer (containing a 100-fold excess of unlabelled thymidine) to remove excess radiolabelled thymidine and the cultured cells were dispersed with $\mathrm{KOH}\left(0.1 \mathrm{~mol} \mathrm{I}^{-1}\right)$ with $1 \%$ Triton- $X 100$. The DNA was precipitated with trichloroacetic acid (Fisher Scientific, $10 \%$ $\mathrm{w} / \mathrm{v}$ ) and the radioactivity of the pellet was measured.

\section{Partial purification of follicular fluid supernatant}

The FFS collected from small, medium and large follicles was pooled (to maximize the amount of protein recovered) and 
centrifuged at $7000 \mathrm{~g}$ for $15 \mathrm{~min}$ to remove any particulate components. The clear supernatant was then serially filtered (by centrifugation) through micro-concentrators (Centricon filters, Amicon, Danvers, MA) with membranes with molecular mass cutoff points of $10 \mathrm{kDa}$ and $30 \mathrm{kDa}$; this yielded three fractions containing proteins in the molecular mass ranges $<10,10-30$ and $>30 \mathrm{kDa}$. Different doses of each of these fractions were tested for their effects on $\left[{ }^{3} \mathrm{H}\right]$ thymidine incorporation as described above.

\section{Polyacrylamide gel electrophoresis of FFS fractions}

The fractionated FFS was subjected to polyacrylamide-gel electrophoresis (PAGE). One-dimensional PAGE was performed under denaturing conditions with sodium dodecyl sulfate PAGE (SDS-PAGE) and also under non-denaturing conditions according to the methods described by Laemmli (1970) and Maizel (1974) using $1 \mathrm{~mm} \times 16 \mathrm{~mm}$ gels. Resolving gels contained $18 \%$ acrylamide (acrylamide:bis $=37.5: 1$ ) and stacking gels were $4 \%$ acrylamide and measured $2 \mathrm{~cm}$. Two sets of standards were used: (i) Sigma MW-ND-500 (Sigma Chemicals, St Louis, MO): albumin, bovine serum ( $66 \mathrm{kDa})$; albumin, chicken egg ( $45 \mathrm{kDa})$; carbonic anhydrase, bovine erythrocytes $(29 \mathrm{kDa}) ; \alpha$-lactalbumin, bovine milk (14.2 kDa); and (ii) Sigma GF-70 (Sigma Chemicals): albumin, bovine serum $(66 \mathrm{kDa})$; carbonic anhydrase $(29 \mathrm{kDa})$; cytochrome $c(12.5 \mathrm{kDa})$; aprotinin $(6.5 \mathrm{kDa})$.

Standards were prepared by dissolving a mixture of $1 \mathrm{mg}$ each of the four proteins in $1 \mathrm{ml}$ of electrophoresis buffer and $10-20 \mu \mathrm{l}$ of the mixed solution was loaded on the wells. Partially purified FFS protein samples were mixed with $10 \%$ glycerol $(30 \mu \mathrm{l}$ in $300 \mu \mathrm{l}$ of FFS fraction) and $0.1 \%$ of bromophenol blue ( $10 \mu \mathrm{l}$ of a stock solution containing $3 \mathrm{~g} \mathrm{ml}^{-1}$ ) and loaded on to $1 \mathrm{~cm}$ wells.

FFS proteins were separated electrophoretically by applying a current of $30-50 \mathrm{~mA}$ per gel until the tracking dye reached the bottom edge of the gel (about 3-4 h). For the non-denaturing PAGE analysis, prior to application of samples, the gels were conditioned by pre-electrophoresis for $1 \mathrm{~h}$ to remove the harmful agents used in acrylamide polymerization.

Protein bands in the gels were stained for $3 \mathrm{~h}$ with Coomassie Blue and then destained. For the non-denaturing PAGE, the whole gel was sliced longitudinally into two halves, one containing the lanes with the standards and the other with lanes containing the FFS proteins; the half containing the standards was stained and the remaining half was quickly frozen on dry ice for subsequent bioassay of eluted proteins.

\section{Assay for activity of proteins separated by non-denaturing $P A G E$}

The activity of proteins localized on non-denaturing PAGE was tested by their effect on incorporation of thymidine into granulosa cell DNA in a short-term bioassay $(8 \mathrm{~h})$. The frozen gel was sectioned into $1 \mathrm{~mm}$ slices using a Mickles Gel Slicer (Brinkman Instruments, NY) and the slices were transferred to $10 \mathrm{~mm} \times 75 \mathrm{~mm}$ glass tubes (five slices per tube) containing $700 \mu \mathrm{l}$ of cell culture buffer (McCoy's 5A with $1 \%$ fetal calf serum). The tubes were incubated at $37^{\circ} \mathrm{C}$ with gentle shaking for $6 \mathrm{~h}$ to elute the protein.

Aliquots of $500 \mu \mathrm{l}$ of the buffer containing the eluted proteins were added to $400 \mu$ l of cell suspension containing
$1.25 \times 10^{5}$ viable granulosa cells. The cells were incubated with the eluted FFS proteins for $36 \mathrm{~h}$ at $37^{\circ} \mathrm{C}$ and then $\left[{ }^{3} \mathrm{H}\right]$ thymidine was added $(0.5 \mu \mathrm{Ci}$ per well in $0.1 \mathrm{ml})$ and incubation was continued for another $4 \mathrm{~h}$. Incubation was terminated and the incorporation rate was measured as described previously.

\section{Blood sampling and gonadotrophin assays}

For determination of the exact timing of the gonadotrophin surges and their blockage, blood samples were collected from two groups of rats every $2 \mathrm{~h}$, between 32 and $40 \mathrm{~h}$ after the first $\mathrm{DES}$ injection. One group received pentobarbital $\left(37 \mathrm{mg} \mathrm{kg}^{-1}\right.$ body weight in $0.2 \mathrm{ml}$ of saline) at $30 \mathrm{~h}$; the intraperitoneally other group (controls) received saline only as vehicle. Concentrations of LH and FSH in serum samples were determined by the double antibody radioimmunoassay method as described by O'Conner et al. (1982) and Rao and Mahesh (1986). Purified LH and FSH standards and first antibodies for LH (NIAMDDrLH-S7; dilution = I:234 125) and FSH (NIAMDD-rFSH-SII; dilution $=1: 125000$ ) were obtained from the Rat Pituitary Distribution Program of the National Institute of Arthritis, Metabolic and Digestive Diseases (NIAMDD). Second antibody (dilution $=1: 250$ ) was purchased from Arnell Inc. (Brooklyn, NY). Standard curve ranges of the assays were 1-256 ng LH per tube and 4-512 ng FSH per tube and percentage bindings were $16-20$ and $25-30 \%$, respectively. Intra- and interassay variations were 5.8 and $10.8 \%$, respectively, for FSH and 7.9 and $11.2 \%$, respectively, for $\mathrm{LH}$.

\section{Statistical analysis}

Results were analysed by one-way analysis of variance (ANOVA) and Tukey's multiple-range test using the STATGRAPHICS statistical program (Statistical Graphics Corporation, STSC, Inc).

\section{Results}

Effect of diethylstilboestrol treatment on $\left[{ }^{3} \mathrm{H}\right]$ thymidine incorporation and time of killing

Incorporation rates in granulosa cells from small follicles (Fig. 1) did not vary significantly with increasing number of DES injections or with variation in time of kill after two injections (Expt 1); but in the medium follicles, the significant stimulatory effect seen $24 \mathrm{~h}$ after the second injection was lost when $48 \mathrm{~h}$ was allowed to elapse between the second injection and killing. Furthermore, three and four injections were inhibitory to incorporation in these follicles, as reported earlier (Chakravorty et al., 1991b). In the large follicles, significant stimulation was seen after two injections, but this effect was not sustained with increasing time or number of injections.

\section{Effects of variation of time of killing after the second injection}

Protein content of FFS (Fig. 2a) was measured and no significant differences were found in the small follicles with variation of time of killing after the second injection (Expt 2). Protein 


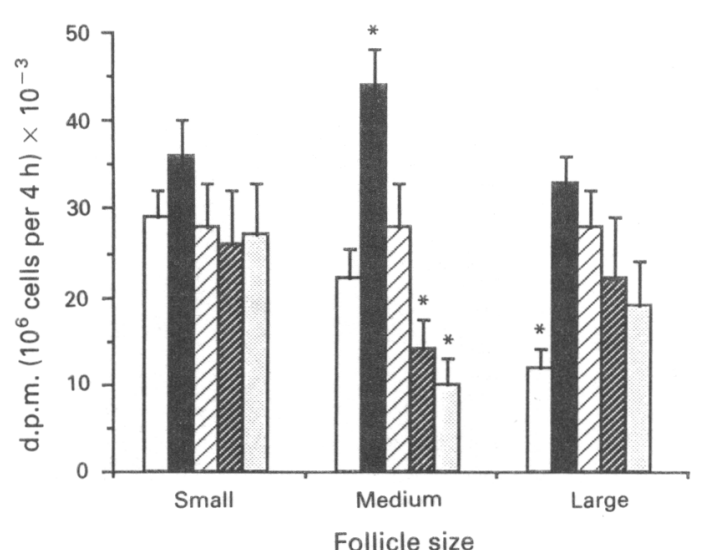

Fig. 1. Incorporation of $\left[{ }^{3} \mathrm{H}\right]$ thymidine in rat granulosa cells from small, medium and large follicles after $(\square)$ one, $(\square, \square)$ two, (包) three or (圈) four injections of diethylstilboestrol $(2 \mathrm{mg}$ per rat). Animals receiving two injections were killed either $24(\boldsymbol{a})$ or $48 \mathrm{~h}(\square)$ after the second injection. Data are means \pm SEM from four experiments, each with pooled ovaries from 10-12 rats. Values within each follicle size were compared between treatments and those for medium and large follicles were significantly different between treatment groups $\left({ }^{*} P<0.01\right)$.

content of the large follicles increased $24 \mathrm{~h}$ after the second injection, but this increase was not maintained $48 \mathrm{~h}$ after the second injection. Protein content in the medium follicles increased at $48 \mathrm{~h}$.

When tested for effects on $\left[{ }^{3} \mathrm{H}\right]$ thymidine incorporation (Fig. 2b), FFS protein from the large follicles was stimulatory at $24 \mathrm{~h}$ after the second injection, but this effect was reduced after a further $24 \mathrm{~h}$, indicating that it was transient. In contrast, FFS protein from the medium follicles had no effect at the earlier time, but significantly inhibited incorporation $48 \mathrm{~h}$ after the second DES treatment. FFS protein from the small follicles had no effect.

\section{Protein content of FFS after treatment with pentobarbital to block gonadotrophin surges}

It has been shown that two injections of diethylstilboestrol given to intact rats produce a gonadotrophin surge at $36 \mathrm{~h}$ (Chakravorty et al., 1991a). The effect of these surges on FFS protein content and peptide activity was investigated by blocking both FSH and LH surges with pentobarbital, given at $30 \mathrm{~h}$ (Expt 3). When pentobarbital was given $6 \mathrm{~h}$ before the expected surge time and serum content of gonadotrophins was assayed every $2 \mathrm{~h}$ for the following $10 \mathrm{~h}$, both FSH (Fig. 3a) and LH (Fig. 3b) were completely blocked. Removal of the gonadotrophin surges increased follicular protein content in the medium follicles (Fig. 4), but decreased it in the large follicles.

\section{Effects of FFS protein after pentobarbital treatment}

In animals that were killed $48 \mathrm{~h}$ after the second DES injection, FFS protein from medium follicles (Fig. 5a) significantly inhibited thymidine incorporation; 150 and $300 \mu \mathrm{g}$ of unfractionated FFS protein inhibited incorporation in a dose-dependent manner. Furthermore, pentobarbital blockage of gonadotrophin surges
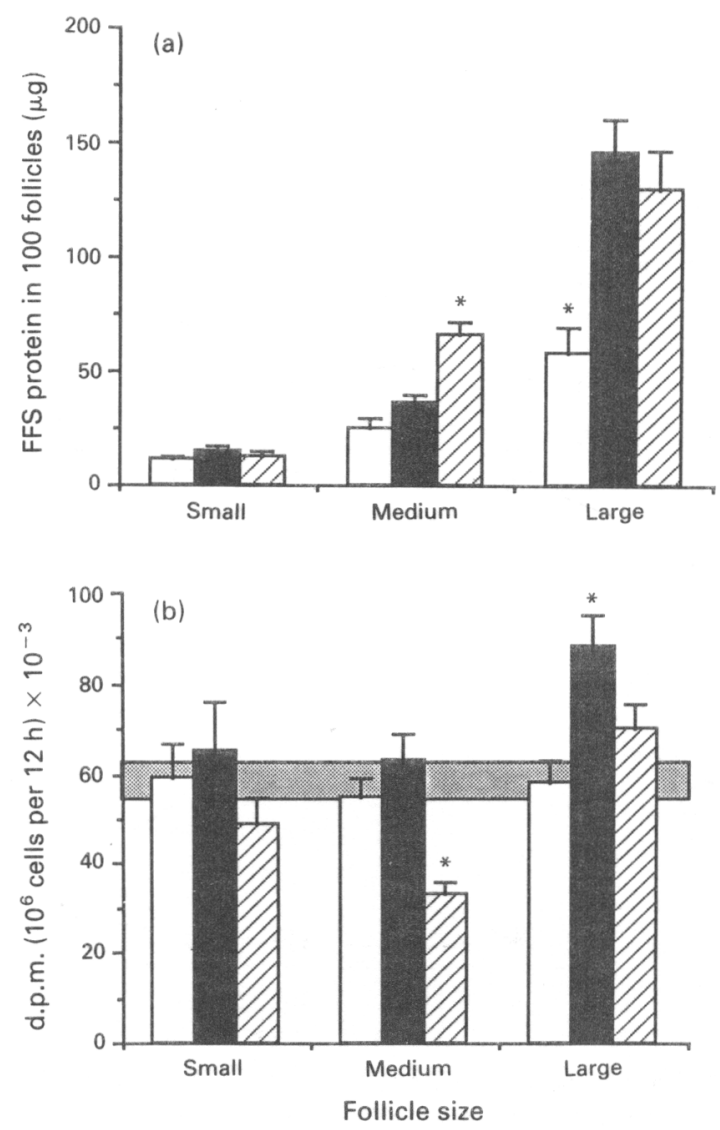

Fig. 2. (a) Protein content of small, medium and large rat follicles and (b) effects of the follicular fluid protein on $\left[{ }^{3} \mathrm{H}\right]$ thymidine incorporation following one ( $\square$ ) or two injections of diethylstilboestrol (DES, $2 \mathrm{mg}$ per rat), the latter groups being killed at $24(\boldsymbol{D})$ or $48 \mathrm{~h}(\mathrm{~V} \lambda)$ after the second injection. Data are means \pm SEM from four experiments, each with pooled ovaries from 10-12 rats. Control values \pm SEM in (b) are denoted by the shaded area. Values have been compared for each follicle size between treatment groups $\left({ }^{*} P<0.05\right)$. Protein content and inhibitory activity of follicular fluid supernatant (FFS) from medium follicles increased at $48 \mathrm{~h}$, whereas protein content increased in the large follicles and it was stimulatory at $24 \mathrm{~h}$ after the second DES injection.

did not affect the degree of inhibitory activity in the FFS; there was no significant difference between pentobarbital- or vehicletreated groups. FFS protein from the medium and large follicles was stimulatory when FFS was collected $24 \mathrm{~h}$ after the second DES injection. The effect was greater in the large follicles and at a lower dose of the total protein $(150 \mu \mathrm{g})$, but the stimulatory effects were lost when FFS was collected $48 \mathrm{~h}$ after the second injection. However, in the large follicles, pentobarbital treatment not only abolished the stimulatory effects seen with $150 \mu \mathrm{g}$ (Fig. 5a), but was also significantly inhibitory at a dose of $300 \mu \mathrm{g}$ of the total FFS protein (Fig. 5b). The decrease in protein synthesis in large follicles seen after gonadotrophin blockage (Fig. 4) could have stimulated granulosa cell proliferation particularly, since an increase in FFS protein in large follicles $12 \mathrm{~h}$ after the gonadotrophin surge correlated with a concomitant increase in thymidine incorporation with $150 \mu \mathrm{g}$ of the protein at this time. Furthermore, a decline in concentration or a loss of activity of this peptide took place with time, 

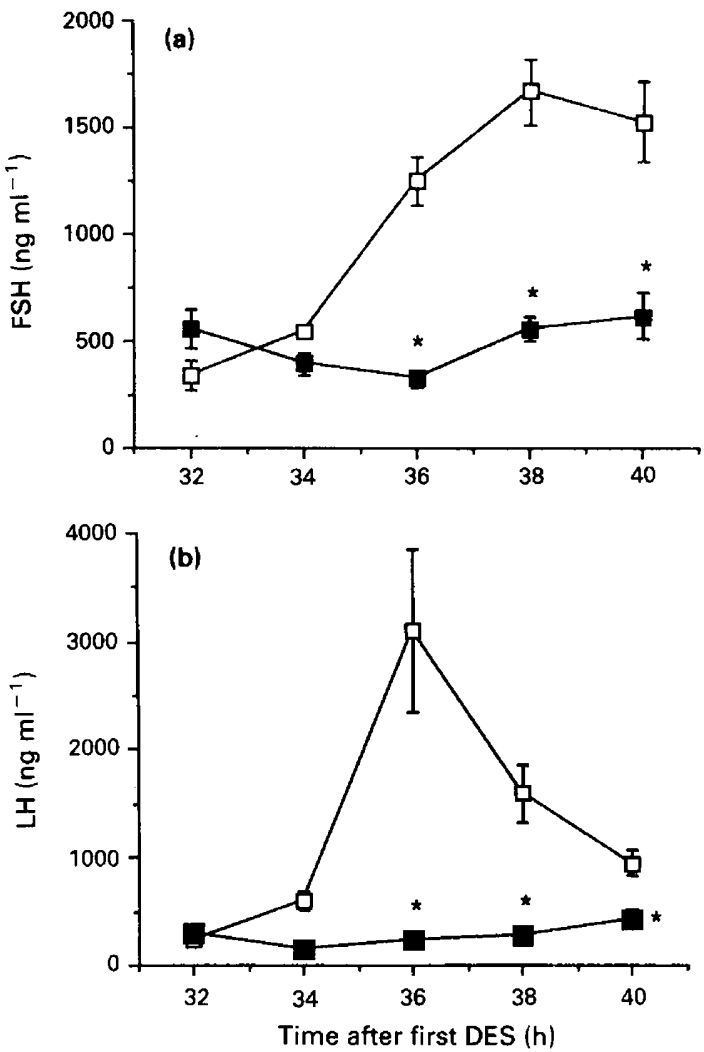

Fig. 3. Serum concentrations of (a) follicle-stimulating hormone (FSH) and (b) luteinizing hormone (LH) following treatment of rats with vehicle $(\square)$ or pentobarbital ( $\square, 37 \mathrm{mg} \mathrm{kg}^{-1}$ body weight), given $6 \mathrm{~h}$ after the second diethylstilboestrol (DES) injection. Data are means \pm SEM from two experiments, each with nine animals per treatment group. "Values significantly different from controls $(P<0.01)$.

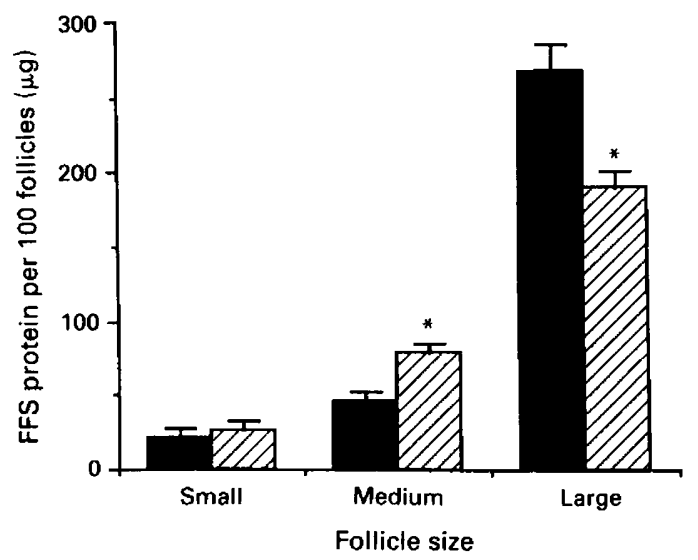

Fig. 4. Protein content of follicular fluid supernatant (FFS) from small, medium and large rat follicles after two injections of diethylstilboestrol (DES; $2 \mathrm{mg}$ per rat) at 0 and $24 \mathrm{~h}$ followed by saline ( $\mathbf{Q}$ ) or pentobarbital $(\nabla)$ treatment at $30 \mathrm{~h}$. The animals were killed $48 \mathrm{~h}$ after the second DES injection. Data are means \pm SEM from four experiments, each with pooled ovaries from 10-12 rats. Comparisons were made for each follicle size between treatments and protein content increased in medium follicles, but decreased in large follicles significantly $\left({ }^{*} P<0.05\right)$ after blockage of gonadotrophins.

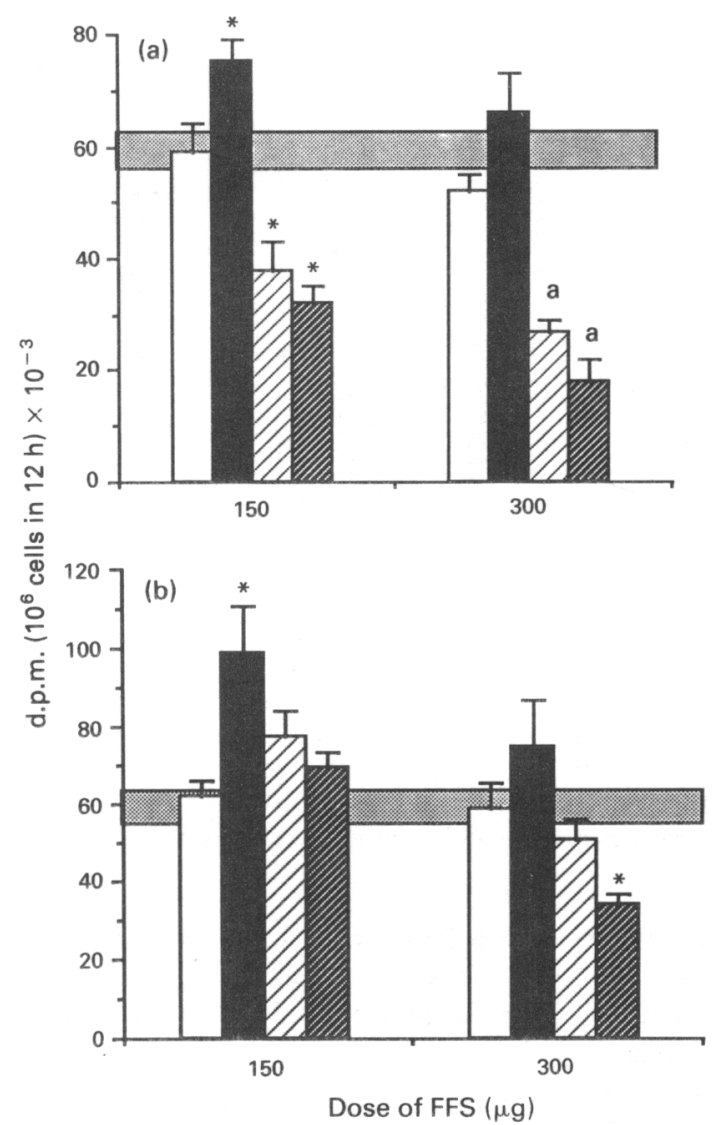

Fig. 5. Effects of 150 and $300 \mu \mathrm{g}$ of follicular fluid supernatant (FFS) from (a) medium and (b) large rat follicles on $\left[^{3} \mathrm{H}\right]$ thymidine incorporation, after treatment with diethylstilboestrol (DES, $2 \mathrm{mg}$ per rat). The treatment groups were $(\square)$ one injection, killed at $24 \mathrm{~h}$; ( $\square$ ) two injections, killed at $24 \mathrm{~h}$; ( $\circlearrowright$ ) two injections plus saline, killed at $48 \mathrm{~h}$; and (W) two injections plus pentobarbital, killed at $48 \mathrm{~h}$. All times of killings depict time since the last injection. Data are means \pm SEM from four experiments. The shaded area represents control \pm SEM values. ${ }^{*}$ Values significantly different from controls $(P<0.01)$. Values with similar superscripts are significantly different from each other ( $\left.{ }^{a} \mathrm{P}<0.05\right)$. FFS protein $(150$ and $300 \mu \mathrm{g}$ ) from medium follicles inhibited incorporation $48 \mathrm{~h}$ after the second DES injection, irrespective of whether gonadotrophins were present or blocked. The inhibition seen with $300 \mu \mathrm{g}$ FFS from medium follicles was significantly greater when gonadotrophins were absent.

resulting in the absence of activity at $48 \mathrm{~h}$ after the second injection ( $36 \mathrm{~h}$ after the surge). However, $300 \mu \mathrm{g}$ of this protein was not stimulatory, probably because, at this higher dose, the concentration of GCMP was sufficient to override the stimulatory effects. It is possible that some of the stimulatory factor was also synthesized in the medium follicles, but its effects were undetectable because of the higher concentration of GCMP in these follicles.

Number of follicles and granulosa cells after pentobarbital blockage of gonadotrophin surges

The number of medium and large follicles (Table 1) increased after two DES injections. This increase did not occur when the 
Table 1. Number of rat follicles and granulosa cells after one or two diethylstilboestrol injections, with or without pentobarbital treatment after the second injection

\begin{tabular}{|c|c|c|c|}
\hline \multirow[b]{2}{*}{ Follicle size } & \multicolumn{3}{|c|}{ Injections } \\
\hline & 1 & 2 & $\begin{array}{c}2+ \\
\text { pentobarbital }\end{array}$ \\
\hline & \multicolumn{3}{|c|}{ Number of follicles per ovary } \\
\hline Small & $146 \pm 20$ & $142 \pm$ & $166 \pm 32$ \\
\hline Medium & $24 \pm \quad 3$ & $46 \pm 3^{a}$ & $26 \pm 4$ \\
\hline \multirow[t]{2}{*}{ Large } & $4 \overline{ \pm}$ & $8 \pm \quad 2^{a}$ & $5 \pm 1$ \\
\hline & \multicolumn{3}{|c|}{ Number of granulosa cells per follicle } \\
\hline Small & $310 \pm 19$ & $306 \pm 11$ & $295 \pm 13$ \\
\hline Medium & $1764 \pm 82$ & $2028 \pm 106$ & $1886 \pm 57$ \\
\hline Large & $3400 \pm 125^{b}$ & $5526 \pm 250^{\mathrm{b}}$ & $1876 \pm 106^{\mathrm{b}}$ \\
\hline
\end{tabular}

Values are means \pm SEM from four experiments, each with $10-12$ rats per treatment group.

Values significantly different from each other within each follicle size have the same superscript letters (a, b; $P<0.05$ ).

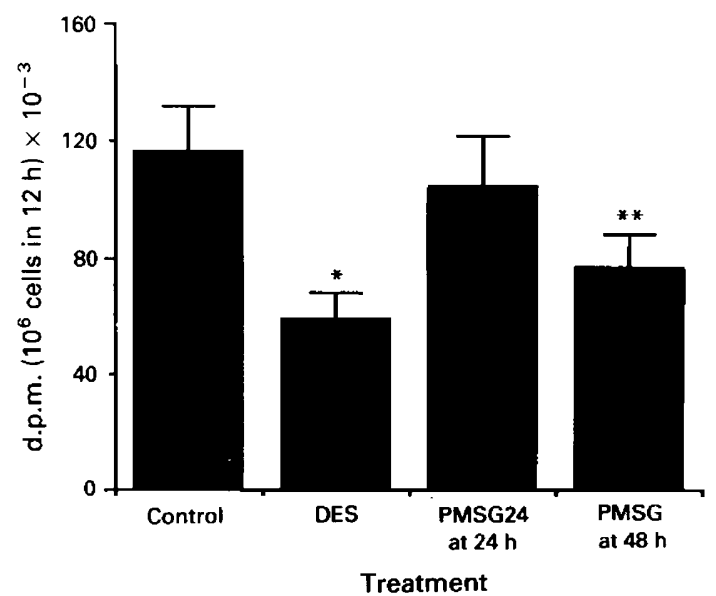

Fig. 6. Effects of follicular fluid supernatant (FFS) on thymidine incorporation after treatment with diethylstilboestrol (DES) or pregnant mares' serum gonadotrophin (PMSG). Rats were treated with DES (four injections), or PMSG and killed 24 or $48 \mathrm{~h}$ later. FFS protein $(250 \mu \mathrm{g})$ from medium follicles was tested for inhibitory effects on $\left[{ }^{3} \mathrm{H}\right]$ thymidine incorporation. Each value represents mean \pm SEM from three experiments, each with 10 animals per treatment group. Values significantly different from controls are denoted by asterisks $\left({ }^{*} P<0.01 ;{ }^{* *} P<0.05\right)$.

gonadotrophins were blocked by pentobarbital treatment of the DES-treated rats. Similarly, the number of granulosa cells increased significantly after two injections, but this increase was prevented by pentobarbital blockage of gonadotrophins. There were no significant differences in number of granulosa cells in the medium or small follicles, suggesting that the gonadotrophins were affecting only the large follicles.

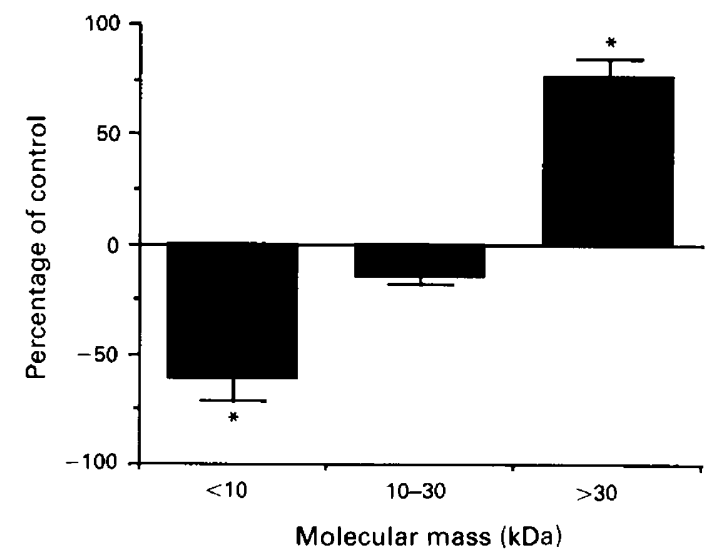

Fig. 7. Effects of microconcentrated follicular fluid supernatant on $\left[{ }^{3} \mathrm{H}\right]$ thymidine incorporation after separation into three fractions of differing molecular mass. Follicular fluid supernatant was collected after pooling all three sizes of follicles to maximize recovery. Data, expressed as percentage of inhibition or stimulation over controls, are means \pm SEM from three experiments, each with pooled ovaries from $10-12$ rats $\left({ }^{*} P<0.01\right)$.

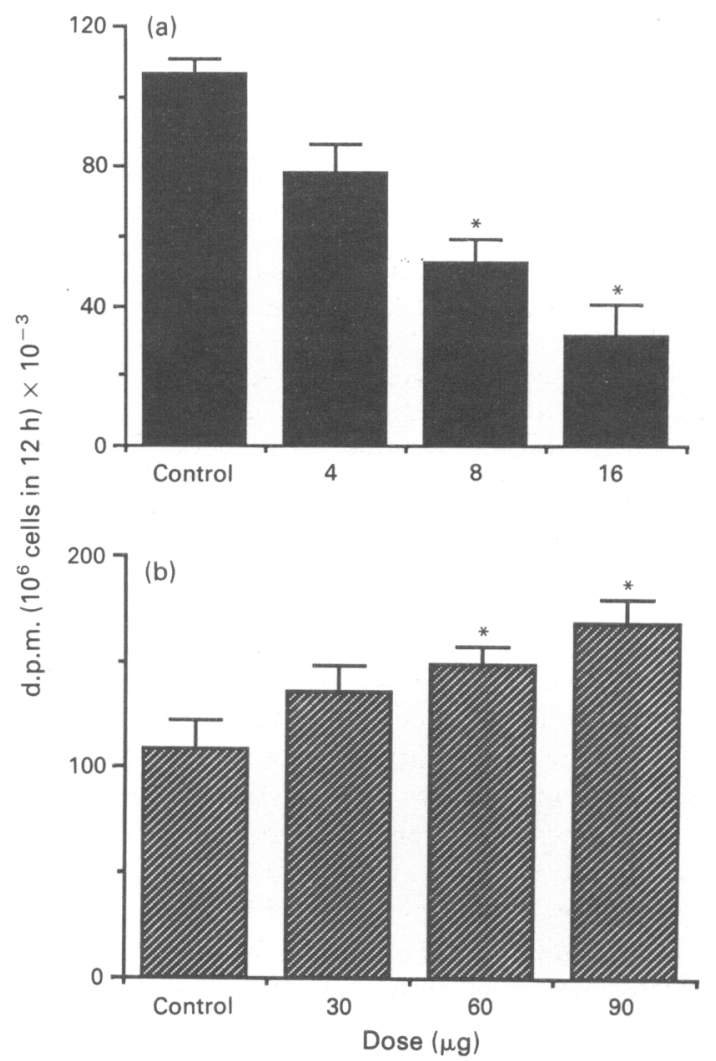

Fig. 8. Dose-dependent effects of rat follicular fluid supernatant fractions (a) $<10 \mathrm{kDa}$ and (b) $>10 \mathrm{kDa}$ on $\left[{ }^{3} \mathrm{H}\right]$ thymidine incorporation. Data are means \pm SEM from three experiments, each with pooled ovaries from 10-12 animals. "Values significantly different from controls $(P<0.05)$. 
(a)

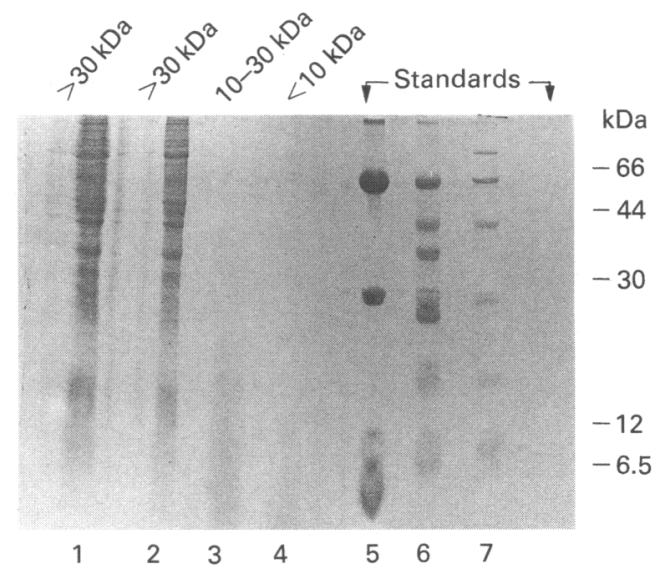

(b)

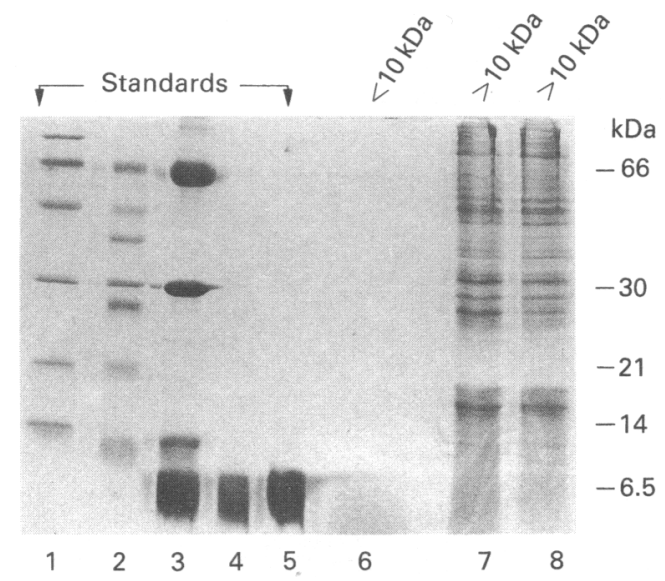

Fig. 9. SDS-polyacrylamide gel electrophoresis of microconcentrated rat follicular fluid supernatant (FFS) proteins showing migration profiles of standard proteins (5-7 (a) and 1-5 (b)). Lanes 4 and 5 in (b) represent one particular standard with molecular mass $6.5 \mathrm{kDa}$ from the Sigma GF 70 set of standards. Lanes 1-4 (a) and 6-8 (b) are FFS samples having different molecular mass ranges. Diffuse bands of proteins are seen in lanes 3 and 4 in (a) and lane 6 in (b) because of low amounts of protein loaded in each lane.

\section{Effect of PMSG treatment on activity of FFS peptide}

The studies with pentobarbital suggested that gonadotrophins had no modulatory role on the actions of the inhibitory peptide. They also suggested that the peptide was induced by oestrogen. FFS from medium follicles from PMSG-treated ovaries was tested for the presence of inhibitory activity at 24 and $48 \mathrm{~h}$ after treatment (Expt 4): $300 \mu \mathrm{g}$ of FFS protein was inhibitory to thymidine incorporation only after $48 \mathrm{~h}$ of PMSG treatment (Fig. 6), suggesting that inhibitory activity was present when endogenous oestradiol concentrations were high (Chakravorty et al., 1991a).

\section{Effects of fractionated FFS protein}

For these experiments, follicles were isolated and all sizes were pooled for collection and fractionation of FFS protein.

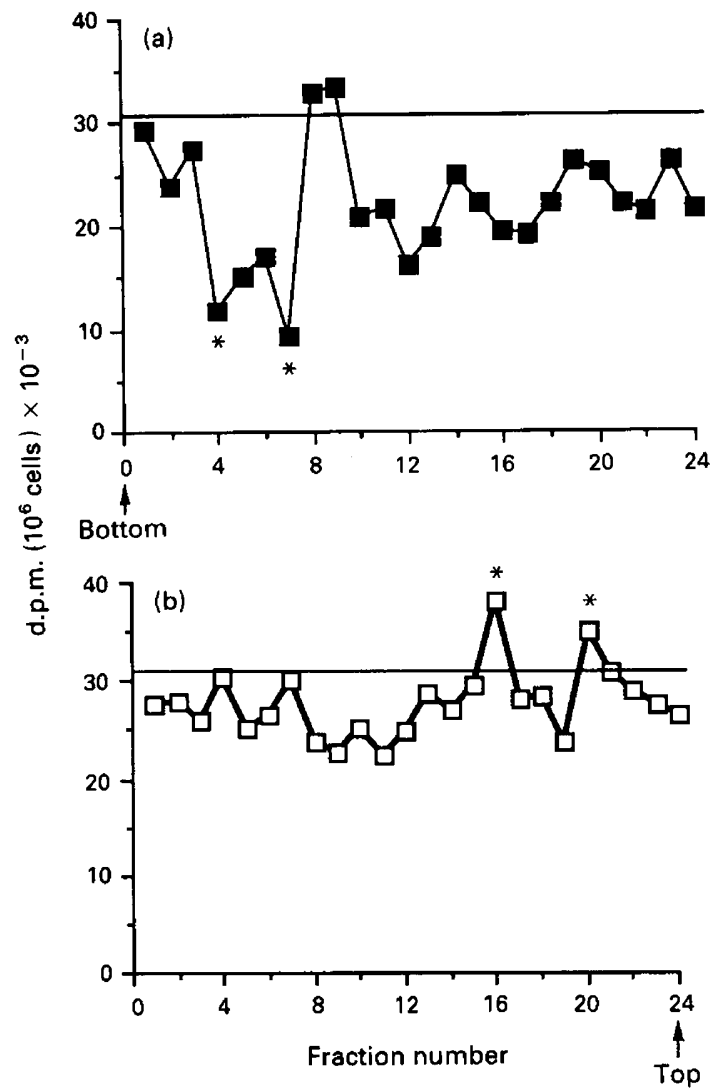

Fig. 10. Effects of rat follicular fluid supernatant proteins with molecular mass range of (a) $<10 \mathrm{kDa}$ and (b) $>10 \mathrm{kDa}$ on $\left[{ }^{3} \mathrm{H}\right]$ thymidine incorporation after separation by non-denaturing polyacrylamide gel electrophoresis and elution from the $0.5 \mathrm{~cm}$ gel slices. This experiment was repeated and identical results were obtained, but data from only one experiment are shown. The horizontal line represents control values. ${ }^{*}$ Values significantly different from controls $\left({ }^{*} P<0.05\right)$.

Proteins with molecular masses $<10 \mathrm{kDa}$ were inhibitory, while proteins with molecular masses $>30 \mathrm{kDa}$ had significant stimulatory effects (Fig. 7). The proteins with molecular masses 10-30 kDa were inhibitory, but this inhibition was not statistically significant. Different doses of the partially purified FFS protein fractions were tested for their effects on $\left[{ }^{3} \mathrm{H}\right]$ thymidine incorporation. Doses between 4 and $16 \mu \mathrm{g}$ of the fraction of molecular mass $<10 \mathrm{kDa}$ showed a linear dose-dependent inhibition (Fig. 8a). A dose of $60-90 \mu \mathrm{g}$ of the $>30 \mathrm{kDa}$ fraction was stimulatory (Fig. 8b). Non-specific effects of blood-borne factors in FFS were eliminated by fractionating serum from rats treated with four DES injections into ranges of $<10 \mathrm{kDa}$ and $>10 \mathrm{kDa}$, and $100 \mu \mathrm{g}$ of each fraction was tested for effects on $\left[{ }^{3} \mathrm{H}\right]$ thymidine incorporation. Both fractions stimulated incorporation rates by $20-30 \%$ over controls (data not shown).

\section{PAGE of FFS fractions}

Of the three fractions obtained after microconcentration of FFS, the $>30 \mathrm{kDa}$ fraction showed several well-defined bands (Fig. 9), but these were not seen in the other $<10 \mathrm{kDa}$ fraction. However, this fraction showed diffuse protein bands in the 
appropriate molecular mass ranges, confirming accuracy of microconcentration.

\section{Effects of proteins eluted from non-denaturing $P A G E$}

FFS proteins were fractionated into those with molecular mass $<$ and $>10 \mathrm{kDa}$. Each fraction was further separated electrophoretically by a non-denaturing polyacrylamide gel. The separated proteins were eluted from the gels and tested for effects on $\left[{ }^{3} \mathrm{H}\right]$ thymidine incorporation (Fig. 10). Two peaks of inhibitory activity were found in the $<10 \mathrm{kDa}$ fraction, corresponding to $0.9-1.3 \mathrm{kDa}$ and $1.7-2.3 \mathrm{kDa}$. Two peaks of stimulatory activity were detected with molecular mass $>10 \mathrm{kDa}$, corresponding to molecular masses of $22-26$ and $34-38 \mathrm{kDa}$.

\section{Discussion}

The role of hormones in the regulation of mitosis of granulosa cells during follicle development is unclear. Gonadotrophins affect granulosa cell proliferation only in certain stages of follicles in hamsters (Roy and Greenwald, 1988), whereas, in rats, follicles having diameters $>350-400 \mu \mathrm{m}$ are affected maximally by the FSH surge (Hirshfield, 1985). FSH and oestradiol treatment of hypophysectomized rats results in rapid granulosa cell proliferation and follicle growth (Rao et al., 1978), but the stimulatory effects are not sustained with prolonged treatment, suggesting that, even though these hormones are mitogenic, their actions are limited. When the FSH surge is prevented by barbiturates, there are fewer follicles of $>450 \mu \mathrm{m}$ in diameter at oestrus, suggesting that, besides recruiting primary follicles, FSH stimulates granulosa cell multiplication in large $(>400 \mu \mathrm{m})$ follicles. The findings of the present study support this concept by showing that gonadotrophin blockage leads to a reduction in the number of granulosa cells in large follicles.

The second established mitogenic stimulus for granulosa cell proliferation is oestrogen. We have reported that oestrogen can be stimulatory as well as inhibitory depending on follicle size and that inhibition of medium follicles was via a peptide (Chakravorty et al., 1991b), which we have named GCMP. The present study confirms the existence of GCMP not only in the DES model, but also in a commonly used, more physiological model: the PMSG-treated immature rat model. In both models, inhibitory activity was found $48 \mathrm{~h}$ after the last injection, only after oestrogen concentrations had been high for some time. In addition, a transient stimulatory effect was seen with FFS from large follicles, which was possibly due to the gonadotrophin surge that occurred $12 \mathrm{~h}$ after the second DES injection. Since LH has been shown to inhibit follicle growth in hamsters (Roy and Greenwald, 1986b), it is also likely that the gonadotrophins, and not DES, were responsible for modulating the activity of GCMP. We tested this hypothesis by collecting FFS protein from follicles of different sizes after oestrogen treatment, and testing for effects on $\left[{ }^{3} \mathrm{H}\right]$ thymidine incorporation, in the presence and absence of gonadotrophins. Hence, the objective of the study was to investigate gonadotrophic and oestrogenic regulation of FFS factors and their characterization.

Our results suggest that the stimulatory peptide was dependent upon gonadotrophins (probably FSH) and that the production of GCMP was dependent upon oestrogen. This was confirmed by using pentobarbital to block the gonadotrophins. We found that the effect of GCMP predominated when the synthesis of the stimulatory peptide was prevented by blocking gonadotrophins. The stimulatory peptide had an effect only when the more potent GCMP was present at a lower concentration in the large follicles. Pentobarbital caused an increase in protein in medium follicles and a decrease in protein in large follicles. Since such a differential effect of pentobarbital was seen on FFS protein concentrations in follicles of different sizes, it is unlikely that pentobarbital caused a non-specific effect on protein synthesis. However, pentobarbital is known to have a deleterious effect on ovarian physiology, inducing atresia of follicles (Terranova, 1980; Uilenbroek et al., 1980); the effect of pentobarbital on granulosa cells seen in the present study could be a generalized one, further augmenting the oestrogenic effect. We have already expressed reservations about the DES model (Chakravorty et al., 1991a), and, hence, the PMSG model was also used to demonstrate the effects of GCMP. The DES/ pentobarbital model was used only to generate enough GCMP for further characterization.

The effects of the peptide were also reflected in numbers of follicles and granulosa cells (Table 1 ). The increase in number of medium follicles seen at $48 \mathrm{~h}$ in controls was probably due to FSH driving the growth of smaller follicles into the mediumsized pool resulting in an increase in the number of medium follicles. This increase did not occur when FSH was blocked. However, the total number of granulosa cells was not affected; we propose that, at this stage, FSH is not the primary mitogenic stimulus in medium follicles. Rather, it is oestrogen, particularly because at this time the concentrations of GCMP were probably not sufficient to retard DNA synthesis and cell proliferation. Hence, there was no decrease in number of granulosa cells in the medium follicles, thereby demonstrating an apparent dissociation between numbers of granulosa cells and follicles in the FSH-deficient animals. Numbers of granulosa cells and large follicles increased in the presence of FSH and significantly decreased when FSH was blocked, suggesting that gonadotrophins were affecting the large follicles maximally and specifically.

Oestrogen and gonadotrophin modulation of follicle growth via the synthesis of GCMP and the stimulatory peptide found in this study could account for the follicle growth patterns reported in rats and hamsters. In rats, Hirshfield and Midgley (1978) have shown that, while follicles of $<390 \mu \mathrm{m}$ diameter are present on all days of the cycle, there is a discontinuous movement of follicles of this size range into the pre-Graafian size range. Follicles of $390-500 \mu \mathrm{m}$ were totally absent at proestrus, but appeared at oestrus. This could be due to the FSH surge on the afternoon of proestrus, stimulating the production of a growth stimulatory factor which causes follicles of $350-450 \mu \mathrm{m}$ to grow. The cessation of growth of follicles of $<390 \mu \mathrm{m}$ at proestrus could be due to the presence of GCMP in these medium-sized follicles. According to Hirshfield (1983), the size range of $350-450 \mu \mathrm{m}$ is an FSH-regulated turning point in the developmental process. Prior to this stage, intraovarian factors such as high oestrogen or androgens may be more important in determining granulosa cell proliferation. According to the findings of Hirshfield (1983), by the time the follicles have reached a diameter of $390 \mu \mathrm{m}$, 'selection' has 
already taken place and apparently, at this point, the follicles require high FSH for only a short period. This would explain the transient nature of activity of the gonadotrophin-induced stimulatory peptide seen in the present study. Moreover, the stage of development which is dependent upon high concentrations of FSH corresponds approximately to the time when the follicles are $350-500 \mu \mathrm{m}$ in diameter (Hirshfield, 1983). The FSH dependency of this class of follicle (classified as large in the present study) could be due to the proposed stimulatory factor.

In hamsters, it has been shown that DNA synthesis following the FSH surge differs with the stage of the follicle development (Roy and Greenwald, 1986a). The proestrus rise in FSHstimulated DNA synthesis was evident in stages 2-4 and 9 and 10, while stages 5-7 were unaffected. The same pattern was seen when FSH was given exogenously (Roy and Greenwald, 1986b). These findings once again demonstrated that only the early and penultimate stages of granulosa cell mitosis during follicle growth are regulated by FSH, while the intermediate stages are under intragonadal control.

Physical and biochemical characterization of the FFS collected from the different-sized follicles was difficult because of the extremely limited quantities of the samples. However, partial characterization of the two peptides was attempted first by microconcentration and then by PAGE. We found that the inhibitory peptide (GCMP) was localized in the $10 \mathrm{kDa}$ fraction. A similar protein of molecular mass $10 \mathrm{kDa}$ is present in ovine follicular fluid which inhibits $\left[{ }^{3} \mathrm{H}\right]$ thymidine incorporation in fibroblasts (Carson et al., 1988). The stimulatory effects were found in the molecular mass range of $>30 \mathrm{kDa}$. Dose-dependent effects were seen with both fractions, but were more pronounced with $<10 \mathrm{kDa}$ proteins, supporting our previous postulation that inhibitory effects of GCMP were more potent and that GCMP was present at a greater concentration, leading to overriding of the effects of the stimulatory peptide.

It has been hypothesized that several angiogenic factors are produced in the ovary in response to gonadotrophins and oestrogens causing hyperaemia of the ovary (Koos and Le Maire, 1983). The possibility that the inhibitory peptide is blood-borne was tested by fractionating serum from rats treated with four DES injections, and effects of the fractions on $\left[{ }^{3} \mathrm{H}\right]$ thymidine incorporation were tested. Corresponding serum fractions did not exhibit any inhibitory effects, suggesting that the factor was of intra-ovarian origin and not present in an ultrafiltrate of serum.

Experiments using SDS-PAGE were not successful in determining the exact molecular masses of the two peptides. Well-defined bands were not evident, particularly with the $<10 \mathrm{kDa}$ fraction probably because only a small amount of the proteins $(25-50 \mu \mathrm{g})$ was loaded on to the gel and because the proteins did not withstand denaturing with SDS. However, SDS-PAGE did verify the purity of the different fractions obtained by microconcentration. The two peaks of inhibitory activity could be GCMP $(1.8-2.3 \mathrm{kDa})$ and a degradation product or a monomeric form of GCMP $(0.9-1.2 \mathrm{kDa})$. The two peaks of stimulatory activity, one corresponding to 22$26 \mathrm{kDa}$ and the other to $34-38 \mathrm{kDa}$ are likely to be transforming growth factor- $\beta$ (a homodimeric $25 \mathrm{kDa}$ protein) and the FSH-dependent stimulatory peptide found in the present study (about $36 \mathrm{kDa}$ ). It has been shown that transforming growth factor- $\beta$ stimulates DNA synthesis in rat granulosa cells
(Dorrington et al., 1988); Knecht ef al. (1986) have shown that FSH does stimulate the synthesis of proteins of molecular masses 25 and $36 \mathrm{kDa}$ among several other proteins, in granulosa cell cultures. They also found that continued presence of FSH or high concentrations of CAMP were required to maintain the synthesis of these proteins. This could explain the transient production of the stimulatory $30 \mathrm{kDa}$ peptide found $12 \mathrm{~h}$ after the gonadotrophin surge in the present study and by loss of activity with time and after blocking the FSH surge.

It has become evident that granulosa cells in large follicles form a heterogeneous population, with distinctive differences between peripheral, antral and pericumulus cells with regard to enzyme content, morphological characteristics, receptor content and mitogenic properties (Greenwald and Terranova, 1988). We have not attempted to relate the effects of the FFS peptides to the different granulosa cell types, but mitotic properties of the peri-antral granulosa cells show evidence of being influenced by the surrounding follicular fluid. These cells, which are in direct contact with follicular fluid components, proliferate the most, showing extensive labelling (Hirshfield, 1986). Incipient atretic changes are also noted first in these cells, the earliest reflection of which is reduced $\left[{ }^{3} \mathrm{H}\right]$ thymidine uptake (Hay et al., 1979; Peluso et al., 1980).

Several peptides regulate granulosa cell function (Savion and Gospodarowicz, 1980; Richards et al., 1983). Most of these proteins are detected by their biological properties, but little is known about their hormonal regulation. Each phase of granulosa cell proliferation is said to be associated with the induction of specific proteins in response to separate hormonal cues. Expression of these proteins could be time-dependent and could vary with the stage of follicle development (Knecht et al., 1986). Characterization and identification of these ovarian proteins would result in a better understanding of the processes involved in granulosa cell mitosis - a key feature in follicle growth. The data presented in this study show the presence of both positive and negative autocrine/paracrine regulators of granulosa cell mitosis, which are under the control of different hormones. Both FSH and oestrogens are mitogenic in vivo, but neither hormone is effective in vitro (Richards, 1979), suggesting that specific factors are induced locally within the gonad by these hormones. A recent report has shown the presence of several mitotic regulators within follicles (Hammond and English, 1987). In the present study, the detection of both stimulatory and inhibitory peptides in follicular fluid supernatant, which are controlled by separate hormones, shows that granulosa cell proliferation is under multifactorial regulation. The process is not simple but is dictated by several regulatory elements (May et al., 1990). The relative concentration of the two peptides reported here may be instrumental in directing the process of granulosa cell proliferation, while other factors, such as the number of granulosa cells in the follicle and the concentration of such steroids as androgens, may be, indirectly, contributing to the process by creating an environment conducive to either peptide action. We suggest that medium follicle growth is regulated primarily by the oestrogen-induced inhibitory peptide that we have named 'granulosa cell mitostatic peptide (GCMP)'. This peptide is potent enough to make cessation of mitosis a rule rather than an exception in medium follicles and, hence, the majority of these follicles are directed towards the atretic pathway. Only medium follicles that have a lower concentration of GCMP and, hence, 
possess a full complement of granulosa cells (McNatty et al., 1979) are capable of further growth into large follicles. These large follicles are controlled primarily by gonadotrophins, particularly FSH via the synthesis of stimulatory peptide. Hence, our study demonstrates the presence of two opposing factors acting together to strike a delicate balance in regulating the extent of granulosa cell proliferation and thereby determining the ultimate fate of the follicles.

This work was supported in part by grant HD 24488 and was presented in part at the twenty-fourth annual meeting for the Society for the Study of Reproduction, Vancouver (1991). The authors wish to thank V. S. Stopper for valuable technical assistance.

\section{References}

Adashi EY, Resnick CE, Brodie AMH, Svoboda ME and Van Wyk JJ (1985) Somatomedin-c mediated potentiation of FSH-induced aromatase activity of cultured rat granulosa cells Endocrinology $1172313-2320$

Bogovich K, Richards JS and Reichert LE (1981) Obligatory role of luteinizing hormone $(\mathrm{LH})$ in the initiation of preovulatory follicular growth in the pregnant rat: specific effects of human chorionic gonadotrophin and follicle stimulating hormone on $\mathrm{LH}$ receptor and steroidogenesis in theca, granulosa and luteal cells Endocrinology 109 860-867

Carson RS, Robertson DM and Findlay JK (1988) Ovine follicular fluid inhibits thymidine incorporation by $3 \mathrm{~T} 3$ fibroblasts in vitro Joumal of Reproduction and Fertility 82 447-455

Chakravorty A, Mahesh VB and Mills TM (1991a) Regulation of follicular development by diethylstilboestrol in ovaries of immature rats. Journal of Reproduction and Fertility 92 307-321

Chakravorty A, Mahesh VB and Mills TM (1991b) Inhibition by diethylstilboestrol of proliferative potential of follicles of different sizes in immature rat ovaries Journal of Reproduction and Fertility 92 323-332

Dorrington JH, Chuma AV and Bendell JJ (1988) Transforming growth factor- $\beta$ and follicle stimulating hormone promote rat granulosa cell proliferation Endocrinology 123 353-359

Gospodarowicz D and Bialecki H (1979) Fibroblast and epidermal growth factors are mitogenic agents for cultured granulosa cells of rodent, porcine and human origin Endocrinology 104 757-761

Greenwald GS and Terranova PF (1988) Follicular selection and its control. In The Physiology of Reproduction Vol. 1 pp 387-446 Eds E Knobil and JD Neill. Raven Press, New York

Hammond JM and English HF (1987) Regulation of deoxyribonucleic acid synthesis in cultured porcine granulosa cells by growth factors and hormones Endocrinology 120 1039-1046

Hay MF, Moor RM, Cran DG and Dott HM (1979) Regeneration of atretic sheep ovarian follicles Journal of Reproduction and Fertility 55 195-207

Hirshfield AN (1983) Compensatory ovarian hypertrophy in the long-term hemicastrate rat: size distribution of growing and atretic follicles Biology of Reproduction 28 271-278

Hirshfield AN (1985) Comparison of granulosa cell proliferation in small follicles of hypophysectomized, prepubertal and mature rats Biology of Reproduction $32979-987$

Hirshfield AN (1986) Patterns of [ $\left.{ }^{3} \mathrm{H}\right]$ thymidine incorporation differ in immature rats and mature cycling rats Biology of Reproduction 34 229-235

Hirshfield AN and Midgley AR, Jr (1978) Morphometric analysis of follicular development in the rat Biology of Reproduction 19 597-605
Knecht M, Shinohara D and Catt KJ (1986) Biosynthesis of cellular and secreted proteins during follicle stimulating hormone-induced granulosa cell differentiation Endocrinology 119 I388-1396

Koos RD and LeMaire WJ (1983) Factors that may regulate the growth and regression of blood vessels in the ovary Seminars in Reproductive Endocrinology 1 295-307

Laemmli UK (1970) Cleavage of structural proteins during the assembly of the head of Bacteriophage T4 Nature 227 680-685

Lobb DK, Skinner MK and Dorrington JD (1988) Rat thecal/interstitial cells produce a mitogenic activity that promotes the growth of granulosa cells Molecular and Cellular Endocrinology 55 209-215

Lowry OH, Rosebrough HF, Farr HL and Randall RF (195I) Protein measurement with the Folin phenol reagent Journal of Biological Chemistry $\mathbf{1 4 3}$ 257-269

McNatty KP, Smith D, Makris A, Osathanondh R and Ryan KJ (1979) The microenvironment of the human antral follicle: interrelationships among the steroid levels in the antral fluid, the population of granulosa cells, and the status of the oocyte Journal of Clinical Endocrinology and Metabolism 49 $851-860$

Maizel JV (1971) Polyacrylamide gel electrophoresis of viral proteins. In Methods in Virology pp 179-246 Eds K Maramarosch and H Koprowski. Academic Press, NY

May JV, Frost JP and Bridge AJ (1990) Regulation of granulosa cell proliferation: facilitative roles of platelet-derived growth factor and low density lipoproteins Endocrinology 126 2896-2905

O'Conner JL, Wolfe RR, Allen MB and Mahesh VB (1982) Effects of neonatal androgenization on the LHRH response of dispersed pituitary cell cultures Archives of Andrology 8 29-35

Peluso JJ, England-Charlesworth C, Bolender DL and Steger RW (1980) Ultrastructural alterations associated with the initiation of follicular atresia Cell and Tissue Research 211 105-115

Rao IM and Mahesh VB (1986) Role of progesterone in the modulation of the preovulatory surge of gonadotropins and ovulation in the pregnant mares serum gonadotropin primed immature rat and the adult rat Biology of Reproduction 35 1154-1161

Rao MC, Midgley AR, Jr and Richards JS (1978) Hormonal regulation of ovarian cellular proliferation Cell 14 71-78

Richards JS (1979) Hormonal control of ovarian follicular development: a 1978 perspective Recent Progress in Hormone Research 35 343-373

Richards IS (1980) Maturation of ovarian follicles: actions and interactions of pituitary and ovarian hormones on follicular cell differentiation Physiological Reviews $6051-73$

Richards JS, Sehgal N and Tash JS (1983) Changes in content and cAMP dependent phosphorylation of specific proteins in granulosa cells of preantral and preovulatory ovarian follicles and in corpora lutea Journal of Biological Chemistry 258 5227-5232

Roy SK and Greenwald GS (1986a) A quantitative analysis of in-vitro incorporation of $\left[{ }^{3} \mathrm{H}\right]$ thymidine into hamster follicles during the oestrous cycle Joumal of Reproduction and Fertility 77 143-152

Roy SK and Greenwald GS (1986b) The effects of FSH and LH on incorporation of $\left[{ }^{3} \mathrm{H}\right]$ thymidine into follicular DNA Journal of Reproduction and Fertility 78 201-209

Roy SK and Greenwald GS (1988) The effects of follicle stimulating hormone, luteinizing hormone and prolactin on follicular deoxyribonucleic acid synthesis in the hamster Endocrinology 122 952-958

Savion N and Gospodarowicz D (1980) Pattern of cellular peptide synthesis by cultured bovine granulosa cells Endocrinology 107 1798-1806

Terranova PF (1980) Effects of phenobarbital-induced ovulatory delay on the follicular population and serum levels of steroids and gonadotrophins in the hamster: a model for atresia Biology of Reproduction 23 92-99

Uilenbroek JTJ, Woutersen PJA and van der Schoot P (1980) Atresia of preovulatory follicles: gonadotrophin binding and steroidogenic activity Biology of Reproduction $23219-229$ 